\title{
Systemic absorption of Soframycin after subconjunctival injection
}

\author{
A. J. BRON, * A. B. RIGHARDS, * D. KNIGHT-JONES, $\dagger$ \\ D. L. EASTY, * AND D. AINSLIE*
}

From the Department of Clinical Ophthalmology, Moorfields Eye Hospital,* City Road, London, and the Nottingham Eye Hospital $\uparrow$

Soframycin* is a member of the neomycin group of aminoglycoside antibiotics. Neomycin as used clinically is a mixture of neomycins B and C, whereas Soframycin is thought to be neomycin B itself (Garrod and O'Grady, I968). It has been established experimentally that both neomycin (Sorsby and Ungar, 1960) and Soframycin (Ainslie and Henderson, 1958) penetrate well into the aqueous humour after subconjunctival injection, and both drugs are used clinically by this route to combat severe ocular infection by a wide range of organisms (Ainslie and Cairns, r96o).

The chemical relationship between neomycin and Soframycin is such that neither drug should be administered systemically except to save life. The possibility that neomycin given subconjunctivally might cause systemic toxicity has been considered, (Sorsby and Ungar, 1960), but no data exist for the systemic absorption of this drug or of Soframycin after subconjunctival injection in man. This paper reports the levels of Soframycin reached in the blood after subconjunctival injection, and the significance of these findings is discussed in relation to available information on systemic toxicity.

The literature on neomycin toxicity is extensive. Systemic neomycin is ototoxic, nephrotoxic, and occasionally vestibulotoxic. In the presence of renal disease excessively high serum levels of the drug may follow systemic administration, so that the risk of ototoxicity is increased.

Deafness may follow a wide range of doses, the old and the young being equally vulnerable, and individual susceptibility plays an important part. A striking feature of the ototoxicity is the interval between the start of therapy and the onset of hearing loss.

The lag is such that deafness may be complained of as long as I to 4 weeks after stopping the drug (Halpern and Heller, I96I; King, I962; Leach, I962). Leach has suggested that there is a gradual build-up of the drug in the endolymph when administration is prolonged for more than a few days. It is relevant that significant levels are found in the cerebrospinal fluid after systemic therapy. Waisbren and Spink (1950) found a level of $\mathrm{I} \cdot 26 \mu \mathrm{g} . / \mathrm{ml}$. in one patient receiving I g. neomycin daily by intramuscular injection.

Once hearing loss has begun there may be a down-hill progression over a period of $\mathrm{I}$ to 3 months (Waisbren and Spink, 1950; Halpern and Heller, 1962) and possibly longer (Leach, 1962). This deterioration continues despite stopping the drug. Deafness may be total and is clinically irreversible, although reversible lesions in the organ of Corti have been noted in the guinea-pig (Friedman, Dadswell, and Bird, 1966).

Hawkins and Lurie (1953) demonstrated in the cat that mild ototoxicity is associated with degeneration of the external hair cells of the organ of Corti followed later by degenera- 
tion of the internal hair cells. The earliest changes occur in the basal turn of the cochlea and this correlates with the clinical manifestation of a high-tone perceptive deafness.

The studies of Massénat-Déroche (1954) showed that Soframycin was similarly ableo to produce auditory damage after parenteral use.

\section{Material and methods}

The subjects in this study were patients undergoing routine intraocular surgery (mainly cataract而 extraction) who received a prophylactic injection of $250 \mathrm{mg}$. Soframycin in $0.5 \mathrm{ml}$. sterile water at the end of the operation; 33 patients, nineteen men and fourteen women, were studied. The mean age was $6 \mathrm{I}$ years (range of $\mathrm{r} 3$ to $8 \mathrm{r}$ ). The subconjunctival injection was delivered into the lower fornix. One patient underwent surgery under local anaesthesia, which included a retrobulbar $\vec{\omega}$ injection of lignocaine and adrenaline and topical cocaine to reinforce surface analgesia. The remaining patients underwent general anaesthesia.

Blood was taken from patients just before subconjunctival injection and again at approximately 1,0 3, and $6 \mathrm{hrs}$ afterwards. In seventeen of the patients, later blood samples were obtained. Bloodio was collected in screw-cap bottles, allowed to clot at room temperature, and centrifuged, and the $\mathrm{g}$ serum was pipetted into bijou bottles for storage at $-40^{\circ} \mathrm{C}$.

In twelve of the patients, a preoperative urine sample was collected, and a further postoperative 24-hr urine sample was obtained and the volume measured. An aliquot of each specimen wascs stored at $-40^{\circ} \mathrm{C}$.

Serum and urine specimens were sent in batches for bioassay to Roussel laboratories, where assays were carried out under the direction of Mr. R. C. Strange.

\section{BIOASSAY}

Assay of Soframycin in serum and urine samples was carried out by a standard cup diffusion meth using Bacillus subtilis as test organism. Standard solutions and test dilutions were made with $0 \cdot \mathrm{I} \overrightarrow{\mathrm{M}}$ $(\mathrm{pH} 7.9)$ phosphate buffer solution. Standards were made up to contain $10 ; 5 ; 2.5 ; 1 \cdot 25$, and $0.625 \mu \mathrm{g} . / \mathrm{ml}$. In the system used it has not been found necessary to make a correction for plasma

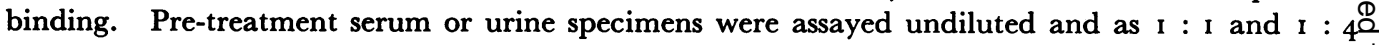
dilutions. After treatment samples were assayed undiluted and as $I: 4$, I $: 9$, and $I:$ ig dilutions. $\overrightarrow{0}$

The diffusion plates were prepared as a base layer of agar containing a suspension of $B$. subtilis spores. A series of $647-\mathrm{mm}$. diameter cups was punched out from each plate to form a latin square, $8 \times 8$, Dilutions of test and standard were pipetted into the cups within the diffusion plate and inhibition: zones were read after $18 \mathrm{hrs}$ ' incubation at $30^{\circ} \mathrm{C}$. Quadruple samples of each dilution of test and응. standard were included in each plate, to exclude errors in assay due to uneven preparation of the plate. Zone diameters within a group were accepted only if they agreed to within $0.2 \mathrm{~mm}$. of their. mean. Standard curves prese prepared for each plate by plotting zone diameters of standardsô against $\log _{10}$ antibiotic concentration and the antibiotic concentration of test solutions were read off the curves and corrected for dilution. The assay is accurate to within \pm 5 per cent.

\section{Results}

A total of 33 patients received $250 \mathrm{mg}$. Soframycin subconjunctivally. In three there weren errors in blood sampling and the results were discarded. In 22 of the remaining thirty N patients, serum Soframycin levels were available for the I to I $\frac{1}{2} \mathrm{hr}$ periods and these were产 grouped together as the "peak" serum levels. In three of these subjects no activity waso recorded in the serum at any time and therefore these results were not included in deriving the mean. The mean peak serum level was $5^{\circ} 07 \mu \mathrm{g} . / \mathrm{ml}$. (with a standard deviation of $2.02 \mu \mathrm{g} . / \mathrm{ml}$.) The serum levels of Soframycin after injection are plotted in the Figure. Values obtained beyond 9 hours after injection are not plotted. The maximum peak 
serum level recorded was $9 \cdot 6 \mu \mathrm{g} . / \mathrm{ml}$. and the minimum detectable peak level was $0 \cdot 6$ $\mu \mathrm{g} . / \mathrm{ml}$. In three patients no antibiotic activity was detected at any time within the first $6 \mathrm{hrs}$. In no subject was antibiotic activity detected in the preinjection serum sample.

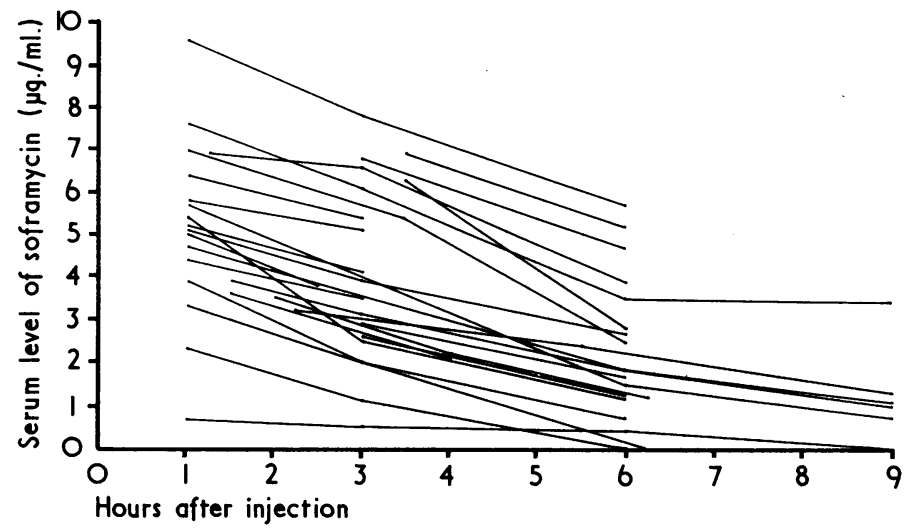

FIGURE Serum levels of Soframycin $(\mu g . / m l$.$) after$ subconjunctival injection in 22 cases

In the seventeen patients, from whom blood was taken later than $6 \mathrm{hrs}$ after injection, the data are patchy but some useful information is available. In five patients, detectable levels of Soframycin were present at $9 \mathrm{hrs}$. In three of these, levels of $0.53,0.57$, and I. I $\mu \mathrm{g} . / \mathrm{ml}$. respectively were present as late as $\mathrm{I} 2 \mathrm{hrs}$ after injection. In one subject, Soframycin was detected at a concentration of $\mathrm{I} \cdot 2 \mu \mathrm{g} . / \mathrm{ml}$. at $25 \mathrm{hrs}$. In the remainder there was no detectable level from 20 to $29 \mathrm{hrs}$ after injection.

A plot of body weight against peak serum levels suggested that a negative correlation might exist between these parameters. However, the correlation coefficient was not found to be statistically significant $(r=-0.383 ; \mathrm{P}>0.05:)$. The urinary excretion of Soframycin was measured in twelve subjects. The Table shows the excretion of Soframycin expressed as a percentage of the dose injected subconjunctivally. The maximum recorded percentage was 33.8 and the minimum 0.9 . In this last subject, and in another in whom only 2 per cent. of the injected dose was excreted, no serum levels of antibiotic were detected.

Table Percentage of subconjunctivally-injected Soframycin excreted in the urine in 24 hours

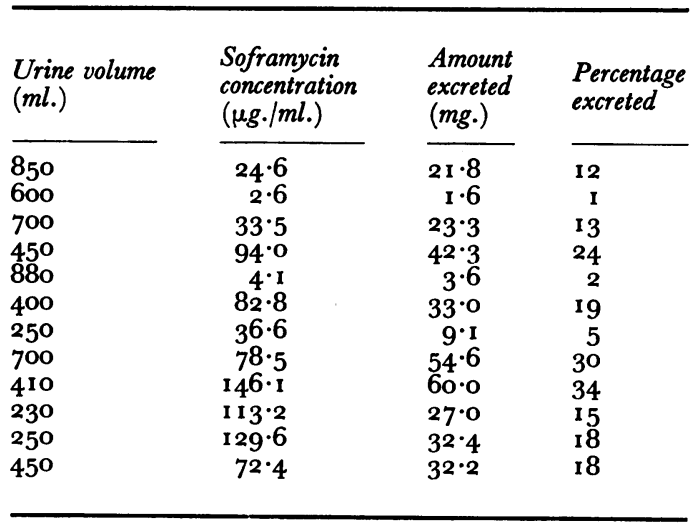

Urinary Soframycin concentrations are expressed as base. Percentage excretion is calculated assuming that $\mathrm{I}, 000 \mathrm{mg}$. framycetin sulphate is equivalent to $710 \mathrm{mg}$. of base. 


\section{Discussion}

These results demonstrate that there is a substantial absorption of subconjunctivally-음 injected Soframycin into the bloodstream. The high serum levels recorded were of $a \stackrel{\Rightarrow}{\Rightarrow}$ similar order to those reported by Massénat-Déroche (1954) after the intramuscular $\stackrel{0}{+}$ injection of $250 \mathrm{mg}$. framycetin sulphate in adult subjects. In his study, peak levels were? reached in $\mathrm{I} \mathrm{hr}$ and the mean peak value in six subjects was $6.5 \mu \mathrm{g} . / \mathrm{ml}$.

In the present study Soframycin was undetectable in the bloodstream of the majority of patients $24 \mathrm{hrs}$ after injection; in a few, it was undetectable after only $6 \mathrm{hrs}$. Though the variation is great, it can be stated that the persistence of the antibiotic in the bloodstream $\vec{\circ}$ is of a similar order after subconjunctival injection to that found after intramuscular injection.

It may be noted that the highest serum level reported by Massénat-Déroche was응. $20 \mu \mathrm{g} . / \mathrm{ml}$, , over twice the maximum level found in the present study. When it is recollected that most of the patients in this study underwent cataract extraction and that this 0 involved opening the conjunctiva, it is clear that the opportunity would exist for loss of a $\frac{G}{\mathrm{G}}$ proportion of the injected antibiotic into the conjunctival sac, and a reason for the lowero levels found here is provided. Some support for this suggestion is given by the urinary excretion values, which were also on the low side. The maximum 24-hr percentage $\mathcal{D}^{\mathcal{S}}$ excretion was 33.8 per cent. Leach ( 1962 ) stated that, in patients with normal renal $\underset{\mathbb{C}}{\circ}$ function, a single intramuscular dose of neomycin is rapidly excreted in the urine in 6 to $\frac{3}{0}$ $8 \mathrm{hrs}$ and is completely cleared from the body in $24 \mathrm{hrs}$. It is not possible to say what is the effect of general anaesthesia on the renal handling of the injected Soframycin, but thos $\vec{\theta}$ may also have been a factor modifying serum levels.

It is likely that in the therapeutic situation, with the conjunctiva intact, higher seruân levels of antibiotic might be expected which would approximate to those seen after intramuscular injection. Though the aim of subconjunctival injection is to achieve a high local concentration of the antibiotic in the eye, the degree of systemic absorption is suffi- $\stackrel{\circ}{\otimes}$ cient to regard it as simply another form of parenteral injection with the same implications $\underset{\overrightarrow{ }}{\overrightarrow{7}}$ of systemic toxicity.

Although the bulk of cases of neomycin toxicity followed its early use as an intra-寻 muscular injection, there is evidence of significant systemic absorption and of toxicity after the administration of the drug by a number of other routes. Poth, Fromm, Wise, and응 Hsiang (1950) recorded a patient with ulcerative colitis who was given neomycin by $\frac{\sigma}{3}$ mouth in a dose of $0.1 \mathrm{~g} . / \mathrm{kg}$. daily, in whom serum levels up to $3 \mu \mathrm{g} . / \mathrm{ml}$. were achieved. In this subject, 3 per cent. of the total oral dose was excreted in the urine. Halpern and Heller ( $196 \mathrm{I}$ ) reported an adult who developed bilateral auditory impairment after $585 \mathrm{~g}$.윽 neomycin given orally to produce intestinal sterilization in hepatic coma. Last and $>$ Sherlock ( 1960 ) reported deafness in a similar patient receiving $560 \mathrm{~g}$. neomycin daily for hepatic failure. The serum neomycin on the day on which deafness developed was $N$ $0.4 \mu \mathrm{g} . / \mathrm{ml}$., but in view of the lag between dosage and the first clinical manifestations of $N$ the toxic effects, it would be unwise to give special significance to this figure. Fuller $\mathcal{E}_{\mathrm{N}}$ ( 1960$)$ reported deafness in two children using neomycin aerosol for staphylococcalo pulmonary infection. The period of medication exceeded 2 years in each case though extending over a greater length of time. Campanelli, Grimes, and West (1966) reported hearing loss in a 5-year-old child who received irrigation of an infected knee sinus with a solution of Io per cent. neomycin over a period of 9 days (approximately $240 \mathrm{~g}$. neomycin 0 being delivered to the joint). 
Deafness after the irrigation of empyema cavities has been reported by a number of workers, and of particular interest is the report of Helm (I96o) of deafness in an adult after four weekly intrapleural injections of $\mathrm{I} \mathrm{g}$. neomycin, only $4 \mathrm{~g}$. neomycin in all.

It is not possible to find in the literature the levels of neomycin in the bloodstream which may be regarded as toxic. It does not appear to be known for how long a minimum serum level must act to produce toxic effects in man and the absolute toxic level is also not known. For this reason, it is difficult to define a safe subconjunctival injection regime for Soframycin or indeed for any drug which is potentially systemically toxic. On the other hand, Soframycin is of proven therapeutic value in the treatment of ocular infection and after over so years of clinical use no report of systemic toxic effects has been made. It would be rash to modify clinical use without such evidence, and obviously similar considerations would apply to other ototoxic drugs, such as streptomycin, kanamycin, vancomycin, and gentamycin; particularly when, like kanamycin and vancomycin, they are also nephrotoxic.

Sorsby and Ungar ( 1960 ) have cautioned against the use of more than four consecutive daily doses of $500 \mathrm{mg}$. each of neomycin subconjunctivally because of the toxic potential of the drug. In the absence of any information to the contrary it would appear safe to employ a similar regime for the adult patient using Soframycin. On the other hand, in those circumstances where it might be expected that such a regime would produce unduly high serum levels, dosage should be modified. This is the case in patients with renal disease, and in infants and children.

In the presence of renal failure, systemically absorbed neomycin shows a cumulative rise with repeated dosage (Last and Sherlock, 1960). It would be simple to measure blood urea in patients about to receive multiple subconjunctival injections of Soframycin and, in the presence of renal failure, to monitor serum levels of the antibiotic and adjust subsequent dosage accordingly.

Similar arguments would suggest modification of the dose of subconjunctival Soframycin in children, where the full adult subconjunctival dose would represent a proportionately larger body weight dose. A higher and more sustained level of the antibiotic in the bloodstream would be anticipated than in the adult. It is salutary to recall that ototoxicity has been recorded with an oral dose of as little as $2 \mathrm{~g}$. neomycin given to an infant treated for viral enteritis (King, 1962). This dose is equivalent to four 500-mg. subconjunctival injections, and one may assume that absorption from the subconjunctival space is greater than from the gastrointestinal tract.

In further studies it is intended to measure serum levels after the injection of $500 \mathrm{mg}$. doses subconjunctivally. The effect of combining adrenaline with the injection will also be examined. It is common to include adrenaline in the solution for injection to increase local absorption and prolong the persistence of the antibiotic in the eye (Sorsby and Ungar, 1960). Experimentally it can be shown that adrenaline also results in lower antibiotic levels in the bloodstream after subconjunctival injection (Sorsby and Ungar, 1947). In clinical use such an effect would be of value in reducing systemic toxicity. It is also intended to carry out a prospective study of audiometric performance in patients receiving subconjunctival Soframycin in order to detect subclinical ototoxicity.

\section{Summary}

(I) The systemic absorption of Soframycin after the subconjunctival injection of $250 \mathrm{mg}$. has been studied in patients after routine intraocular surgery. 
(2) The levels reached in the bloodstream are of a similar order to those seen after intramuscular injection. The mean peak serum level was $5.07 \mu \mathrm{g} . / \mathrm{ml}$. and the maximum $\frac{0}{3}$ recorded was $9.6 \mu \mathrm{g} . / \mathrm{ml}$. In the majority of patients the antibiotic was undetectable in the serum 24 hrs after injection.

(3) In view of these findings and since Soframycin is potentially an ototoxic, nephrotoxic, and vestibulotoxic drug, it is suggested that ophthalmologists should use a lower dose regime for infants and children and that extra caution should be exercised in the treatment of patients with impaired renal function.

(4) There appears to be no need to alter the recommended dose regime in adults in the absence from the literature of definite reports of systemic toxicity.

It is a pleasure to record our thanks to Dr. A. Atkinson and Mr. R. G. Strange of Roussel Laboratories for 0 their collaboration in the study, as well as to Mr. J. R. Sendak who performed the statistical analysis. Our $\mathcal{E}$ thanks are also due to Prof. B. R. Jones for discussion and criticism of work in preparation.

\section{References}

AINSLIE, D., and CAIRNS, J. E. (1960) Brit. J. Ophthal., 44, 25

-- and HENDERSON, W. G. (1958) Ibid., 42, $5^{13}$

Gampanelli, P. A., Grimes, E., and West, m. L. (1966) Med. Ann. D.C., 35, 54I

friedman, i., Dadswell, J. v., and Bird, E. s. (ig66) F. Path. Bact., 92, 4I5

FULLER, A. J. (1960) Lancet, 1 , 1026

GARROD, L. P., and o'GRADY, F. (I968) “Antibiotics and Chemotherapy”, 2nd ed., p. I04. ston, Edinburgh

HALPERN, E. B., and HeLleR, M. g. (1961) Arch. Otolaryng., 73, 675

haWkins, J. E., JR., and LURIE, м. I1. (1953) Ann. Otol. (St. Louis), 62, I 128

HELM, W. M. (1960) Lancet, 1, 1294

KING, J. T. (1962) 7. med. Ass. Ga, 51, 530

LAST, P. м., and ShERLOcK, s. (1960) New Engl. F. Med., 262, 385

LEACH, W. (1962) F. Laryng., 76, 774

MASSÉNAT-DÉROCHE, B. (1954) "La Framycétine (un nouvel antibiotique)". Thèse, Paris, No.

346, p. 213

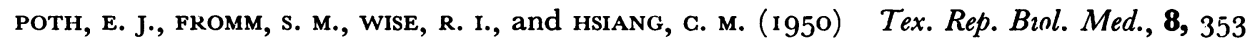

SORSBY, A., and UNGAR, J. (1947) Brit. F. Ophthal., 31, 5 I 7

University Press, L.ondon

WAISBREN, B. A., and SPINK, w. w. (1950) Ann. intern. Med., 33, 099 